\title{
Heterogeneity in influenza seasonality and vaccine effectiveness in Australia, Chile, New Zealand and South Africa: early estimates of the 2019 influenza
}

\section{season}

Sheena G Sullivan ${ }^{1}$, Carmen S Arriola², Judy Bocacao ${ }^{3}$, Pamela Burgos 4 , Patricia Bustos 5 , Kylie S Carville ${ }^{6}$, Allen C Cheng ${ }^{7,8}$, Monique BM Chilver ${ }^{\text {, Cheryl Cohen }}{ }^{10}$, Yi-Mo Deng ${ }^{11}$, Nathalie El Omeiri' ${ }^{12}$, Rodrigo A Fasce ${ }^{13}$, Orienka Hellferscee ${ }^{10}$, Q Sue Huang ${ }^{3}$, Cecilia Gonzalez ${ }^{4}$, Lauren Jelley ${ }^{3}$, Vivian KY Leung ${ }^{1}$, Liza Lopez ${ }^{14}$, Johanna M McAnerney ${ }^{10}$, Andrea McNeill ${ }^{14}$, Maria F Olivares ${ }^{15}$, Heidi Peck $^{11}$, Viviana Sotomayor ${ }^{15}$, Stefano Tempia ${ }^{2,10,16,17}$, Natalia Vergara ${ }^{15}$, Anne von Gottberg ${ }^{10}$, Sibongile Walaza ${ }^{10}$, Timothy

Wood ${ }^{14}$

1. World Health Organization (WHO) Collaborating Centre for Reference and Research on Influenza, Royal Melbourne Hospital, and Doherty Department, University of Melbourne, at the Peter Doherty Institute for Infection and Immunity, Melbourne, Australia

2. Influenza Division, Centers for Disease Control and Prevention, Atlanta, United States

3. National Influenza Centre, Institute of Environmental Science and Research, Wellington, New Zealand

4. Programa Nacional de Inmunizaciones, Ministerio de Salud, Santiago, Chile

5. Sección de Virus Respiratorios y Exantematicos, Instituto de Salud Publica de Chile, Santiago, Chile

6. Victorian Infectious Diseases Reference Laboratory, Royal Melbourne Hospital, at the Peter Doherty Institute for Infection and Immunity, Melbourne, Australia

7. School of Public Health and Preventive Medicine, Monash University, Melbourne, Australia

8. Department of Infectious Diseases, Alfred Health, and Central Clinical School, Monash University, Melbourne, Australia

9. Discipline of General Practice, University of Adelaide, Adelaide, Australia

10. National Institute for Communicable Diseases, Johannesburg, South Africa

11. WHO Collaborating Centre for Reference and Research on Influenza, Royal Melbourne Hospital, at the Peter Doherty Institute for Reference and Research on Influenza, Melbourne, Australia

12. Pan American Health Organization(PAHO)/WHO Regional Office for the Americas, Washington, United States

13. Subdepartamento de Enfermedades Virales, Instituto de Salud Publica de Chile, Santiago, Chile

14. Health Intelligence Team, Institute of Environmental Science and Research, Wellington, New Zealand

15. Departamento de Epidemiologia, Ministerio de Salud, Santiago, Chile

16. Influenza Program, Centers for Disease Control and Prevention, Pretoria, South Africa

17. MassGenics, Duluth, United States

Correspondence: Sheena G Sullivan (Sheena.Sullivan@influenzacentre.org)

Citation style for this article:

Sullivan Sheena G, Arriola Carmen S, Bocacao Judy, Burgos Pamela, Bustos Patricia, Carville Kylie S, Cheng Allen C, Chilver Monique BM, Cohen Cheryl, Deng Yi-Mo, El Omeiri Nathalie, Fasce Rodrigo A, Hellferscee Orienka, Huang Q Sue, Gonzalez Cecilia, Jelley Lauren, Leung Vivian KY, Lopez Liza, McAnerney Johanna M, McNeill Andrea, Olivares Maria F, Peck Heidi, Sotomayor Viviana, Tempia Stefano, Vergara Natalia, von Gottberg Anne, Walaza Sibongile, Wood Timothy. Heterogeneity in influenza seasonality and vaccine effectiveness in Australia, Chile, New Zealand and South Africa: early estimates of the 2019 influenza season. Euro Surveill. 2019;24(45):pii=1900645. https://doi.org/10.2807/1560-7917.ES.2019.24.45.1900645

We compared 2019 influenza seasonality and vaccine effectiveness (VE) in four southern hemisphere countries: Australia, Chile, New Zealand and South Africa. Influenza seasons differed in timing, duration, intensity and predominant circulating viruses. VE estimates were also heterogeneous, with all-ages point estimates ranging from $7-70 \%\left(I^{2}: 33 \%\right)$ for $A\left(\mathrm{H}_{1} \mathrm{~N}_{1}\right)$ pdmog, 4-57\% ( $\left.\mathrm{I}^{2}: 49 \%\right)$ for $\mathrm{A}\left(\mathrm{H}_{3} \mathrm{~N}_{2}\right)$ and $29-66 \%\left(\mathrm{I}^{2}\right.$ : $0 \%$ ) for B. Caution should be applied when attempting to use southern hemisphere data to predict the northern hemisphere influenza season.

In Australia, Chile, New Zealand and South Africa, sentinel surveillance is conducted in primary care and/or hospitals to monitor the timing, intensity and impact of influenza seasons, and to estimate influenza vaccine effectiveness (VE). While the influenza epidemics of these four southern hemisphere countries often coincide, the type of epidemic experienced can vary. Nevertheless, the influenza season experienced in southern hemisphere countries has sometimes been interpreted as a forewarning to the northern hemisphere [1]. Here, we describe the heterogeneity experienced during the 2019 influenza season in these four countries and provide early VE estimates.

\section{Influenza surveillance systems}

The sentinel surveillance systems used in this analysis are described in detail in the Table. For Australia, influenza-like illness (ILI) surveillance data came from the Australian Sentinel Practices Research Network (ASPREN), supplemented by the Victorian Sentinel Practice Influenza Network (VicSPIN) [2]. Hospital surveillance data were obtained from the Influenza Complications Alert Network (FluCAN) [3]. In Chile, severe acute respiratory infection (SARI) sentinel surveillance included seven sentinel hospitals distributed across six of 16 administrative regions [4]. In New Zealand, ILI surveillance leverages general practiceregistered patients in all 20 district health boards, 
Summary of key differences in case and exposure ascertainment for syndromic and virological surveillance and vaccine effectiveness estimation, four southern hemisphere countries, 2019 influenza season

\begin{tabular}{|c|c|c|c|c|}
\hline Characteristic & Australia & Chile & New Zealand & South Africa \\
\hline Source populations ${ }^{a}$ & $\begin{array}{l}\text { ILI: } 394 \text { GPs at sentinel general } \\
\text { practices nationwide participate } \\
\text { in syndromic ILI surveillance; } 222 \\
\text { GPs participate in swab testing; } 21 \\
\text { sentinel hospitals nation-wide }\end{array}$ & $\begin{array}{l}\text { Seven sentinel hospitals in } 6 / 16 \\
\text { regions }\end{array}$ & $\begin{array}{l}86 \text { sentinel practices (ILI } \\
\text { patients) in } 20 \text { district health } \\
\text { boards and four hospitals } \\
\text { (SARI patients) }\end{array}$ & $\begin{array}{l}\text { Syndromic: a healthcare } \\
\text { provider network } \\
\text { Virological and VE: Sentinel } \\
\text { general practices (ILI } \\
\text { patients) in } 6 / 9 \text { regions }\end{array}$ \\
\hline $\begin{array}{l}\text { Period used for } \\
\text { weekly rates }\end{array}$ & $\begin{array}{c}\text { ILI: weeks 1-52 } \\
\text { 2019: weeks 1-39 } \\
\text { Hospitals: weeks 14-44 } \\
\text { 2019: weeks 14-39 }\end{array}$ & $\begin{array}{c}\text { Weeks 1-52 } \\
\text { 2019: weeks 10-33 }\end{array}$ & $\begin{array}{l}\text { Weeks 18-39 } \\
\text { 2019: weeks 18-39 }\end{array}$ & $\begin{array}{l}\text { Weeks 1-52 } \\
\text { 2019: weeks 1-38 }\end{array}$ \\
\hline $\begin{array}{l}\text { Clinical case } \\
\text { definition }\end{array}$ & $\begin{array}{l}\text { ILI: fever or history of } \\
\text { feverAND cough, fatigue/malaise } \\
\text { Hospitals: suspected influenza (not } \\
\text { SARI) }\end{array}$ & $\begin{array}{l}\text { SARI: history of fever, or } \\
\text { measured fever of } \geq 38 C^{\circ} \text { AND } \\
\text { cough AND onset within the last } \\
10 \text { days AND hospitalisation }\end{array}$ & $\begin{array}{l}\text { ILI: acute respiratory illness } \\
\text { with a history of fever or } \\
\text { measured fever of } \geq 38^{\circ} \mathrm{C} \text {, AND } \\
\text { cough, AND onset within the } \\
\text { past } 10 \text { days } \\
\text { SARI: as above, but requiring } \\
\text { hospitalisation }\end{array}$ & $\begin{array}{c}\text { ILI: measured fever }\left(\geq 38^{\circ} \mathrm{C}\right) \\
\text { or history of fever, cough, } \\
\text { onset } \leq 10 \text { days }\end{array}$ \\
\hline Virological testing & $\begin{array}{l}\text { ILI: Around } 50 \% \text { of patients are } \\
\text { Swabbed for testing by RT-PCR at } \\
\text { SA Pathology, Adelaide or the NIC, } \\
\text { Melbourne. } \\
\text { Hospitals: RT-PCR testing done at } \\
\text { each hospital. } \\
\text { Sequencing performed by } \\
\text { WHOCCRRI, Melbourne. }\end{array}$ & $\begin{array}{c}\text { RT-PCR or direct } \\
\text { immunofluorescence followed } \\
\text { by RT-PCR-positive for pan- } \\
\text { negative and influenza-positive } \\
\text { specimens for subtyping. } \\
\text { Testing and sequencing } \\
\text { performed at NIC, Santiago. }\end{array}$ & $\begin{array}{l}\text { RT-PCR testing at NIC, } \\
\text { Wellington. } \\
\text { Sequencing performed by } \\
\text { WHOCCRRI, Melbourne. }\end{array}$ & $\begin{array}{l}\text { RT-PCR testing by NIC, } \\
\text { Johannesburg. } \\
\text { Sequencing performed by } \\
\text { WHOCCRRI, Melbourne or } \\
\text { Worldwide Influenza Centre, } \\
\text { Crick Institute, London. }\end{array}$ \\
\hline $\begin{array}{l}\text { Study period for VE } \\
\text { estimation }\end{array}$ & $\begin{array}{l}\text { ILI: } 28 \text { Apr 2019-9 Oct } 2019 \\
\text { Hospitals: } 1 \text { Apr 2019-16 Aug } 2019\end{array}$ & SARI: 4 Mar 2019-18 Aug 2019 & $\begin{array}{c}\text { ILI and SARI: } 29 \text { Apr 2019-29 } \\
\text { Sep } 2019\end{array}$ & ILI: 15 Apr 2019-18 Aug 2019 \\
\hline $\begin{array}{l}\text { Cases/controls for VE } \\
\text { estimates }\end{array}$ & $\begin{array}{l}\text { ILI: test-positive cases vs test- } \\
\text { negative controls } \\
\text { Hospitals: test-positive cases; } \\
\text { control are the next admitted test- } \\
\text { negative patient ( } \leq 2 \text { weeks) }\end{array}$ & $\begin{array}{l}\text { Test-positive cases vs test- } \\
\text { negative controls }\end{array}$ & $\begin{array}{l}\text { Test-positive cases vs test- } \\
\text { negative controls }\end{array}$ & $\begin{array}{l}\text { Test-positive cases vs test- } \\
\text { negative controls }\end{array}$ \\
\hline $\begin{array}{l}\text { Vaccination status } \\
\text { ascertainment }\end{array}$ & $\begin{array}{c}\text { Medical record, self-report or } \\
\text { vaccination registry }\end{array}$ & $\begin{array}{l}\text { Medical record or vaccination } \\
\text { registries (no verbal reports) }\end{array}$ & $\begin{array}{c}\text { Vaccination registry and } \\
\text { self-report }\end{array}$ & $\begin{array}{l}\text { Medical record or } \\
\text { self-reported }\end{array}$ \\
\hline $\begin{array}{l}\text { Vaccination coverage } \\
\text { among influenza- } \\
\text { negative controls } \\
\text { included in VE } \\
\text { estimates }^{\text {b }}\end{array}$ & $\begin{array}{l}\text { Overall: } 49 \% \text { ILI; } 47 \% \text { hospitals } \\
\text { Adults: } 46 \% \text { ILI; } 41 \% \text { hospitals } \\
\text { Children: } 26 \% \text { ILI; } 33 \% \text { hospitals } \\
\text { Elderly: } 78 \% \text { ILI; } 73 \% \text { hospitals }\end{array}$ & $\begin{array}{l}\text { Overall: } 61 \% \text { SARI } \\
\text { Adults: } 41 \% \text { SARI }^{\mathrm{c}} \\
\text { Children: } 72 \% \text { SARI } \\
\text { Elderly: } 64 \% \text { SARI }^{\mathrm{c}}\end{array}$ & $\begin{array}{l}\text { Overall: } 26 \% \text { ILI; } 33 \% \text { SARI } \\
\text { Adults: } 26 \% \text { ILI; } 36 \% \text { SARI } \\
\text { Children: } 9 \% \text { ILI } \\
\text { Elderly: } 70 \% \text { ILI; } 66 \% \text { SARI }\end{array}$ & $\begin{array}{l}\text { Overall: } 11 \% \text { ILI } \\
\text { Adult: } 11 \% \text { ILI } \\
\text { Children: } 9 \% \text { ILI } \\
\text { Elderly: } 35 \% \text { ILI }\end{array}$ \\
\hline Vaccines licensed & $\begin{array}{l}\text { 〈5 years: Flu Quadri Junior (Sanofi) } \\
\text { <65 years: Afluria Quad (Seqirus), } \\
\text { FluQuadri (Sanofi) and Fluarix Tetra } \\
\text { (GSK) } \\
\geq 65 \text { years: Fluad (Seqiris; trivalent } \\
\text { with B/Yamagata component) }\end{array}$ & $\begin{array}{c}\text { Influvac (Abbott) } \\
\text { (inactivated subunit vaccine) } \\
\text { TIV included a B/Victoria-lineage } \\
\text { component }\end{array}$ & $\begin{array}{l}\text { 6-35 months: Fluarix Tetra } \\
\text { (GSK) } \\
\geq 3 \text { years: FluQuadri (Sanofi), } \\
\text { Influvac (Abbott) } \\
\geq 5 \text { years only: Afluria Quad } \\
\text { (Seqiris) }\end{array}$ & $\begin{array}{c}\text { Vaxigrip (Sanofi Pasteur) } \\
\text { (inactivated split-virion } \\
\text { vaccine) and Influvac } \\
\text { (Abbott) (inactivated subunit } \\
\text { vaccine) } \\
\text { All TIV }\end{array}$ \\
\hline $\begin{array}{l}\text { Target groups for } \\
\text { vaccination }\end{array}$ & $\begin{array}{l}\text { Recommended for all. } \\
\text { Free for pregnant women; people } \\
\text { aged }<5 \text { years or } \geq 65 \text { years; } \\
\text { Aboriginal and Torres Strait Islander } \\
\text { peoples; people aged } 5-64 \text { years } \\
\text { with chronic conditions. }\end{array}$ & $\begin{array}{l}\text { Pregnant women from } 13 \text { weeks } \\
\text { gestation; children aged } 6-59 \\
\text { months, adults aged } \geq 65 \text { years; } \\
\text { poultry and pig farm workers; } \\
\text { patients with chronic conditions } \\
\text { aged 5- } 64 \text { years; carriers of } \\
\text { some risk conditions; healthcare } \\
\text { workers. }\end{array}$ & $\begin{array}{l}\text { Pregnant women; people } \\
\text { aged } \geq 65 \text { years; people } \\
\text { aged }<5 \text { years with a medical } \\
\text { condition that increases } \\
\text { their risk of developing } \\
\text { complications from influenza } \\
\text { and the condition is specified } \\
\text { in the Influenza Immunisation } \\
\text { Programme eligibility criteria; } \\
\text { children aged } \leq 4 \text { years with } \\
\text { previous hospitalisation } \\
\text { for respiratory illness or } \\
\text { with a history of significant } \\
\text { respiratory illness. }\end{array}$ & $\begin{array}{c}\text { Pregnant women at all } \\
\text { stages of pregnancy, } \\
\text { including the post-partum } \\
\text { period; HIV-infected } \\
\text { individuals; adults or } \\
\text { children who are at high risk } \\
\text { for influenza complications } \\
\text { because of underlying } \\
\text { medical conditions or } \\
\text { who are receiving regular } \\
\text { medical care for conditions } \\
\text { such as chronic pulmonary } \\
\text { disease; persons aged } \geq 65 \\
\text { years. }\end{array}$ \\
\hline
\end{tabular}

GP: general practice; GSK: Glaxo Smith Kline; ILI: influenza-like illness; NIC: National Influenza Centre; QIV: quadrivalent inactivated vaccine; SARI: severe acute respiratory illness; TIV: trivalent inactivated vaccine; VE: vaccine effectiveness; WHOCCRRI: World Health Organization Collaborating Centre for Reference and Research on Influenza.

a Numbers are provided for 2019 .

${ }^{\mathrm{b}}$ Children: 6 months -17 years of age; Adults: $18-64$ years of age; Elderly: $\geq 65$ years of age.

c Only patients in a target group for vaccination are included in SARI surveillance in Chile so these numbers do not necessarily reflect coverage in the whole population. 
ca540,000, while SARI surveillance includes four public hospitals in Auckland and Counties Manukau District Health Boards [5]. Syndromic surveillance data from South Africa came from outpatient presentations to a large private healthcare provider network, based on International Classification of Diseases (ICD10) codes for pneumonia and influenza (J9-J11) [6,7]. Virological surveillance in South Africa was conducted through the Viral Watch network [8].

\section{Seasonality}

Weekly 2019 influenza activity rates, e.g. ILI consultations per week, were plotted against the mean weekly rate for influenza seasons from 2013 to 2018. All rates were smoothed using a 3-week moving average. The moving epidemic method (MEM) package [9] in R software version 3.6.1 (R Foundation, Vienna, Austria) was used for calculating means and seasonal thresholds using default values to show the onset and intensity of the season (Figure $1 \mathrm{~A}$ ). The specifications used for the MEM may differ from published national surveillance reports. The onset and peak of the influenza season was at least 5 weeks early in Australia and 1 to 2 weeks early in Chile, New Zealand and South Africa. Activity was well above expected levels in South Africa and very high in Chile, but only reached moderate levels in Australia or New Zealand. The seasons experienced in Chile and South Africa were also much shorter in duration than in Australia and New Zealand.

\section{Virological data}

Virological data are shown in Figure $1 \mathrm{~B}$ and highlight the variation in predominant viruses circulating among countries. For example, while influenza $\mathrm{A}\left(\mathrm{H}_{3} \mathrm{~N}_{2}\right)$ virus clearly predominated in South Africa and was detected at very high levels with the positivity reaching $80 \%$ during the peak period, the predominant virus in Chile was $\mathrm{A}\left(\mathrm{H}_{1} \mathrm{~N}_{1}\right)$ pdmo9. In New Zealand, both influenza $A$ and $B$ viruses were detected; however, their relative frequency differed between ILI and SARI surveillance, with B viruses detected among roughly half (51\%; $604 / 1,179)$ of ILI patients but only a quarter (27\%; $104 / 385)$ of SARI patients.

Genetic characterisation of selected viruses showed further differences among countries, although the number of samples characterised was small. Circulating $\mathrm{A}\left(\mathrm{H}_{1} \mathrm{~N}_{1}\right)$ pdmog viruses were similar, with most falling into subclade 6B.1A-P5 in Australia, New Zealand and Chile. Differences in the predominant circulating clade were observed for $\mathrm{A}\left(\mathrm{H}_{3} \mathrm{~N}_{2}\right)$. Of 192 viruses sequenced in Australia, 186 were $3 \mathrm{C} .2 \mathrm{a} 1 \mathrm{~b}(3 \mathrm{C} .2 \mathrm{a} 1 \mathrm{~b}+131 \mathrm{~K}: \mathrm{n}=$ 182; 3 C.2a1b+135K: $n=4)$, with just six 3C.3a. The majority of $\mathrm{A}\left(\mathrm{H}_{3} \mathrm{~N}_{2}\right)$ viruses sequenced in New Zealand also clustered in clade 3 C.2a1b. In Chile, of 31 viruses sequenced, 13 fell into the clade 3 C.2a1b and 18 to 3 C.3a. A limited selection of only 10 viruses from South Africa suggested co-circulation of $3 \mathrm{C} .2 \mathrm{a} 1 \mathrm{~b}+131 \mathrm{~K}$, $3 \mathrm{C} .2 \mathrm{a} 1 \mathrm{~b}+135 \mathrm{~K}$ and $3 \mathrm{C} .3 \mathrm{a}$ viruses. For influenza B, nearly all viruses characterised in Australian primary care surveillance (107/108) and in New Zealand
(167/169) were $B /$ Victoria lineage viruses, while all 11 influenza B viruses characterised in Chile were B/ Yamagata.

\section{Vaccine effectiveness estimation}

The virological data depicted in Figure $1 \mathrm{~B}$ formed the basis for VE estimation. All systems followed a testnegative design, where the odds ratio (OR) comparing the odds of vaccination among test-positive cases vs test-negative controls was used to derive VE, i.e. $\mathrm{VE}=\left(1-\mathrm{OR}_{\mathrm{adj}}\right) \times 100 \%$ [10]. Estimates were made separately for each country, virus and age group, incorporating covariates considered important by each site (Figure 2). The heterogeneity among estimates within each virus/age group combination was measured by $\mathrm{I}^{2}$ and $\mathrm{T}^{2}$ [11]. All networks were able to provide data for the $A\left(\mathrm{H}_{3} \mathrm{~N}_{2}\right)$ VE. Too few $A\left(\mathrm{H}_{1} \mathrm{~N}_{1}\right)$ pdmog and $B$ cases were detected in South Africa to enable VE estimation.

For $\mathrm{A}\left(\mathrm{H}_{1} \mathrm{~N}_{1}\right)$ pdmo9, heterogeneity was low overall $\left(I^{2}: 22 \%\right)$. For adults, although heterogeneity was not high $\left(I^{2}: 58 \%\right)$, VE estimates ranged from $-6 \%(95 \%$ compatibility interval (Cl): -96 to 42 ) in New Zealand to $72 \%(95 \% \mathrm{Cl}: 51-84)$ among people in a target group for vaccination in Chile. Only Chile was able to provide VE estimates for children (65\%; 95\% Cl: 49-76) and elderly, i.e. adults aged $\geq 65$ years $(74 \% ; 95 \% \mathrm{Cl}$ : 51-86).

For $\mathrm{A}\left(\mathrm{H}_{3} \mathrm{~N}_{2}\right)$, heterogeneity was moderate overall $\left(I^{2}: 49 \%\right)$, but higher for adults $\left(I^{2}: 59 \%\right)$. In Australia, South Africa and New Zealand hospitals, VE point estimates ranged from $34 \%$ to $57 \%$ across age groups; however, in Chile and New Zealand primary care, estimates were often close to or beyond the null.

For influenza B, heterogeneity was low overall ( ${ }^{2}$ : $\left.0 \%\right)$, despite differences in the predominant lineage and the use of trivalent vaccine in Chile but quadrivalent in New Zealand and Australia. Overall VE was lowest in Chile $(29 \%$; $95 \% \mathrm{Cl}:-23$ to 59$)$. Here, the B component for trivalent vaccines included a B/Victoria-like virus, but most viruses circulating were B/Yamagata thereby suggesting this low VE may be attributable to lineage mismatch. Only one VE estimate was available for elderly adults (Chile: $44 \%$; $95 \% \mathrm{Cl}$ : -10 to 72 ) and children (Australia: 55\%; 95\% Cl: 20-76).

\section{Discussion}

We have shown that within countries of the southern hemisphere, the timing, duration and intensity of the influenza seasons, the predominant circulating viruses, and VE all varied in the 2019 influenza season, even between neighbouring countries such as Australia and New Zealand. Similar observations have been reported from Europe [9]. Thus, it appears that activity in one country is not indicative of activity in another country, even when influenza seasons are contemporaneous.

The early VE estimates for the 2019 influenza season in the southern hemisphere presented here were highest for influenza $A\left(\mathrm{H}_{1} \mathrm{~N}_{1}\right)$ pdmog and lowest for 
Influenza activity (A) and influenza detections (B) for Australia, Chile, New Zealand and South Africa, 2019 influenza season

\section{A. Influenza activity plots}

Australia:

Primary care
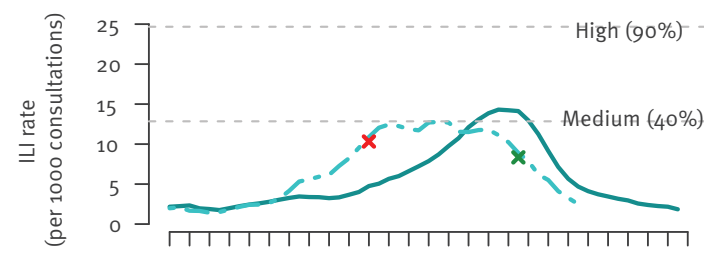

Australia: Hospitals

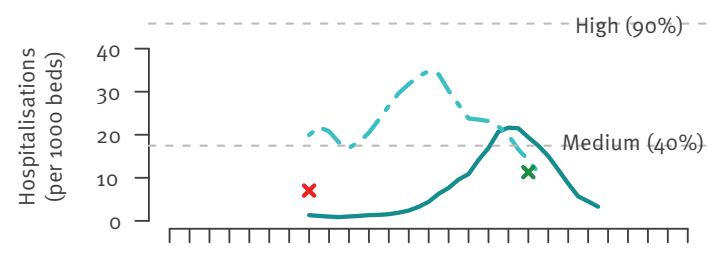

Chile: Hospitals
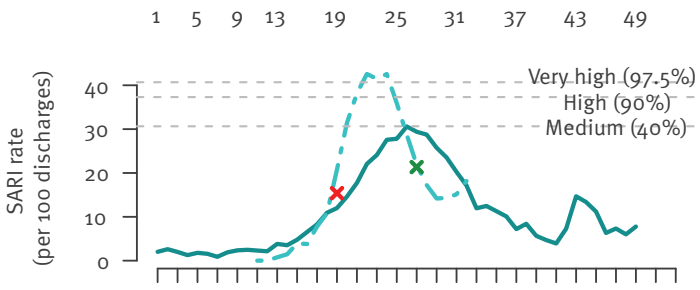

Hospitals

New Zealand: Primary care

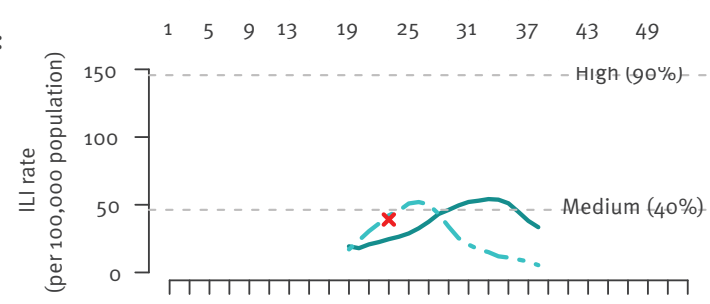

New Zealand: Hospitals
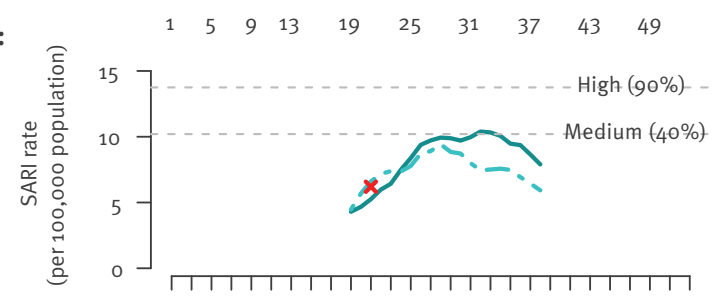

South Africa: Primary care

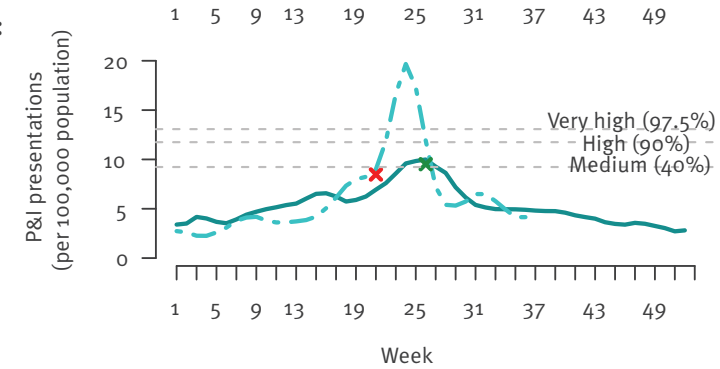

$$
\begin{aligned}
& \text { X Pre-season threshold } \\
& -2013-2018 \text { influenza seasons, } \\
& \text { mean weekly rate }
\end{aligned}
$$$$
x \text { Post-season threshold }
$$

\section{B. Influenza detections by type and subtype}

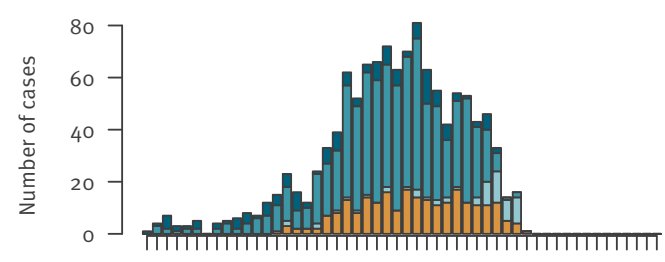

$\begin{array}{lllllllllll}1 & 5 & 9 & 13 & 18 & 23 & 28 & 33 & 38 & 43 & 48\end{array}$
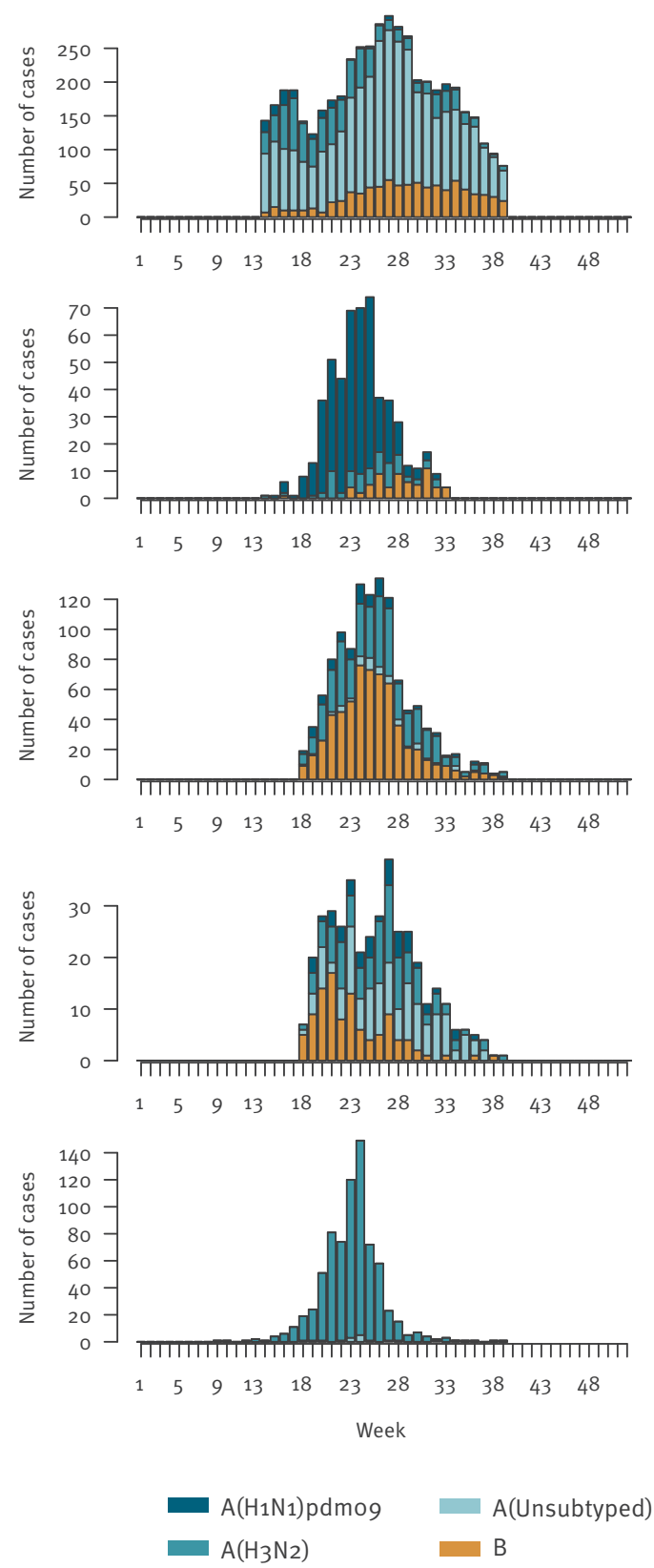

ILI: influenza-like illness; P\&I: pneumonia and influenza; SARI: severe acute respiratory infection.

Influenza activity plots (A) show the intensity of the 2019 influenza season compared with the average for 2013 to 2018 . The point at which 2019 activity crossed baseline thresholds set by the prior 6 years' data are marked with crosses. No post-season thresholds were estimated for New Zealand.

Influenza detections by type and subtype (B) for patients enrolled in hospital and primary care surveillance for VE estimation. The data used in vaccine effectiveness estimation are a subset restricted to those patients with complete information and recruited within the weeks used for estimation (Table). 


\section{FIGURE 2}

Early vaccine effectiveness estimates against influenza A(H1N1)pdm09, A(H3N2) and B by age group and setting, Australia, Chile, New Zealand and South Africa, 2019 influenza season

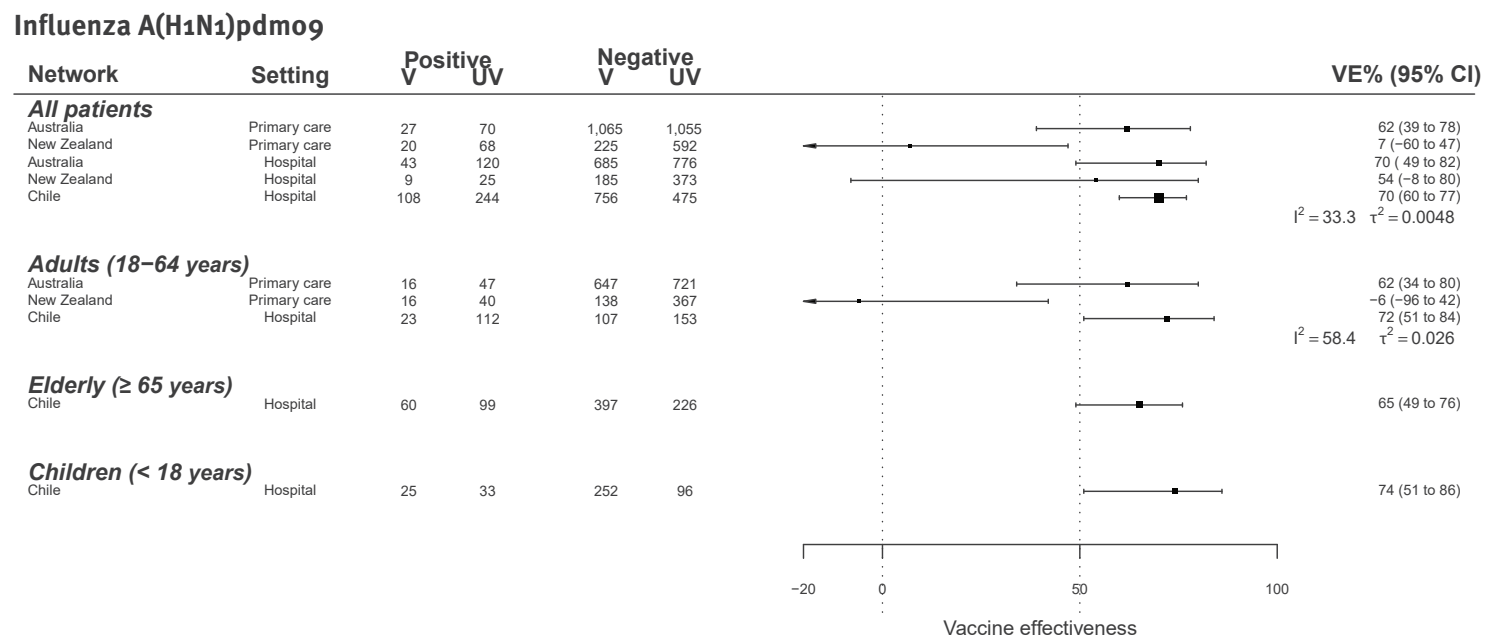

\section{Influenza $\mathrm{A}\left(\mathrm{H}_{3} \mathrm{~N}_{2}\right)$}

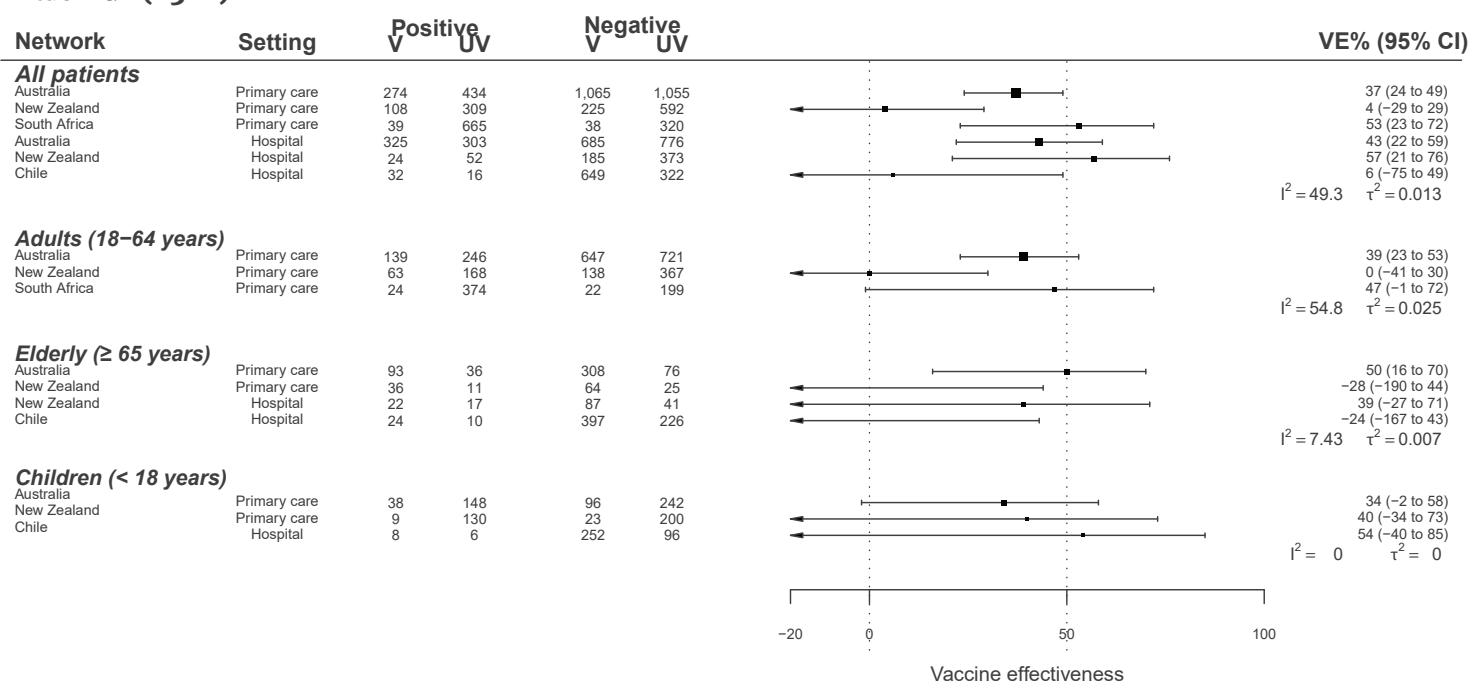

\section{Influenza B}

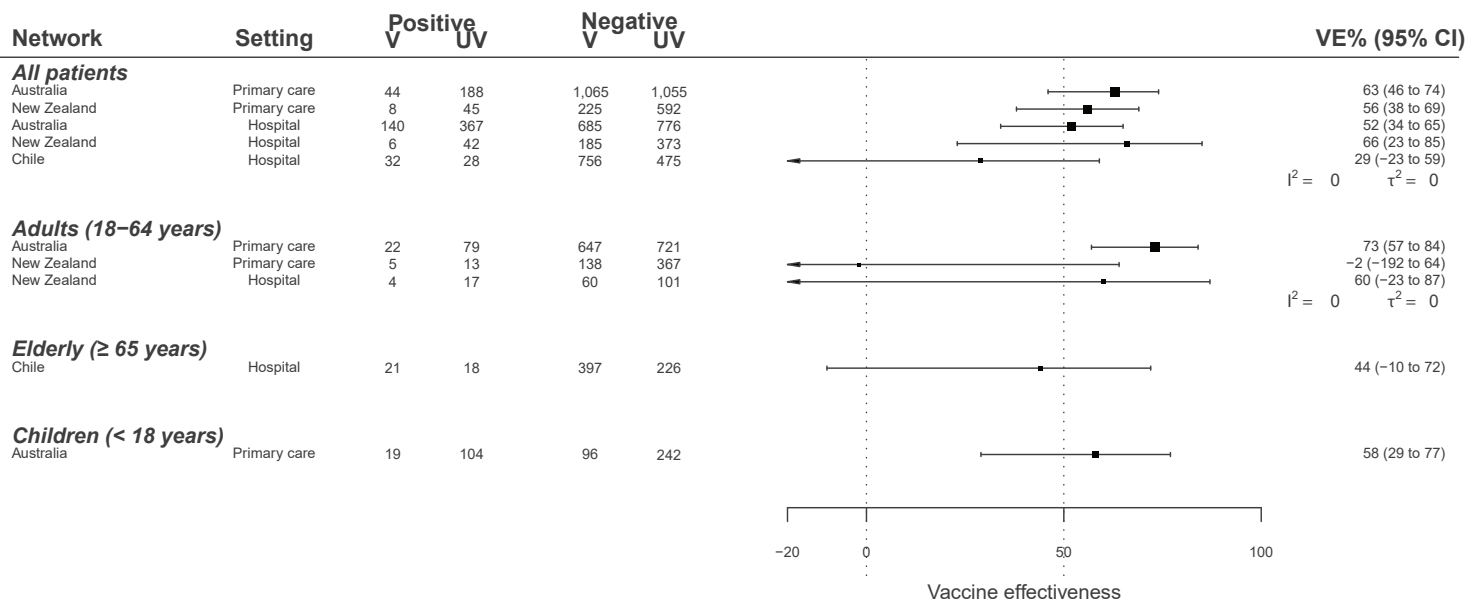

$\mathrm{Cl}$ : compatibility interval; V: vaccinated; UV: unvaccinated; VE: vaccine effectiveness.

$I^{2}$ and $\tau^{2}$ are shown for measures of heterogeneity.

Estimates for Chile only include patients in a target group for vaccination; Australia used adjuvanted TIV for individuals $\geq 65$ years of age.

Covariate adjustment: Australia primary care estimates adjusted for week (restricted cubic spline) and age group (where appropriate); Australia hospital estimates adjusted for age group, comorbidities, indigenous ethnicity and pregnancy; Chile estimates adjusted for age, month of symptom onset and pre-existing conditions; New Zealand estimates adjusted for age group; South Africa estimates adjusted for seasonality and age. 
$A\left(\mathrm{H}_{3} \mathrm{~N}_{2}\right)$. Early estimates often approximate final estimates [12]. However, the utility of these estimates for the northern hemisphere may be limited because the 2019 southern hemisphere vaccine differed from the 2019/20 northern hemisphere formulation in three of four components, $\mathrm{A}\left(\mathrm{H}_{1} \mathrm{~N}_{1}\right)$ pdmog, $\mathrm{A}\left(\mathrm{H}_{3} \mathrm{~N}_{2}\right)$ and $\mathrm{B} /$ Victoria. Nevertheless, these estimates or earlier versions of them were included with other data reviewed at the WHO Consultation and Information Meeting on the Composition of Influenza Virus Vaccines for Use in the 2020 Southern Hemisphere Influenza Season during 23-26 September 2019 in Geneva and provided a general impression of the performance of the 2019 vaccine.

While heterogeneity in our VE estimates did not exceed an $1^{2}$ of $60 \%$, with so few studies, the sensitivity of statistical tests to detect heterogeneity is probably limited. This is exemplified by the $I^{2}$ of $\% \%$ for influenza B estimates among adults despite differences in VE point estimates of 75 percentage points (Figure 2). Thus, low heterogeneity statistics do not alleviate concerns about how to interpret discrepant VE point estimates.

There are many potential sources for this heterogeneity that affect not only the VE estimates, but interpretation of weekly activity rates. First, with random sampling, we should not expect estimates to be the same [13]. Second, when samples are small they may be vulnerable to statistical biases, such as sparse data bias, and bias due to measurement errors may be more profound [14]. Third, there were many differences in study design (Table). Case ascertainment differed; for example, a SARI case definition was used in New Zealand and Chile, but not in Australian hospital surveillance. Exposure ascertainment also differed, with varying availability of registries to verify vaccination status and the use of different vaccines. In particular, the adjuvanted vaccines used among Australians $\geq 65$ years of age might be expected to yield higher VE than standard vaccines [15]. Fourth, vaccine coverage varied (Table). Low vaccination coverage, as observed in South Africa, affects power and precision and can exacerbate the bias induced by measurement errors. Higher coverage, as seen in Chile and among elderly patients in New Zealand and Australia, may mean that many more people in the sample are repeat vaccinees. Repeat vaccination may negatively impact VE and could result in lower VE estimates in highly vaccinated populations [16]. Finally, although only limited virological data were available, we observed differences in circulating $A\left(\mathrm{H}_{3} \mathrm{~N}_{2}\right)$ virus clades and $B$ lineages. This may impact both seasonality and $\mathrm{VE}$, particularly as most $\mathrm{A}\left(\mathrm{H}_{3} \mathrm{~N}_{2}\right)$ viruses sequenced appeared to be in different clades from the vaccine virus ( $\left.3 \mathrm{C}_{2} 2 \mathrm{a}_{2}\right)$. Notably, most $\mathrm{A}\left(\mathrm{H}_{3} \mathrm{~N}_{2}\right)$ viruses were also in different genetic groups from the 2019/20 northern hemisphere vaccine (3C.3a).

In conclusion, we have attempted to briefly summarise and interpret the 2019 influenza season in four southern hemisphere countries and have presented early VE estimates. We observed substantial variation in available data on influenza seasonality and VE within the southern hemisphere in 2019, which is unsurprising given the many differences in surveillance among these countries. Caution should be applied when attempting to infer the impending northern hemisphere influenza season based on these observations.

\section{Ethical statements}

Australia: Data were collected, used and reported under the legislative authorisation of the Australian state and territory legislation, and thus did not require Human Research Ethics Committee approval.

Chile: The institutional review boards at the Pan American Health Organization and United States CDC reviewed the protocol and considered it a vaccination effectiveness evaluation (non-intervention study). Monitoring vaccine effectiveness in Chile is an objective of severe acute respiratory surveillance; thus, ethics committee approval was not needed for data collection and analysis. We did not collect personal identifiers.

New Zealand: Influenza surveillance in New Zealand is conducted in accordance with the Public Health Act and thus ethics committee approval was not needed for collection or use of these data.

South Africa: Influenza surveillance is conducted in accordance with the Public Health Act and thus ethics committee approval was not needed for collection or use of these data.

\section{Acknowledgements}

Australia: We thank Daniel Blakely and Nigel Stocks at University of Adelaide; Violeta Spirotoska at the University of Melbourne; and staff at the Victorian Infectious Diseases Reference Laboratory, SA Pathology and the WHO Collaborating Centre for Reference and Research on Influenza. The Australian Sentinel Practices Research Network, the Influenza Complications Alert NEtwork and the WHO Collaborating Centre for Reference and Research on Influenza are supported by the Australian Government Department of Health.

The Victorian Sentinel Practices Research Network is supported by the Victorian Government Department of Health and Human Services.

Chile: We thank Patricia Bustos, Winston Andrade and Alejandra Acevedo, Sección de Virus Respiratorios y Exantematicos, Instituto de Salud Publica de Chile; Olga López, Hospital Ernesto Torres Galdames, Iquique; Miriam Blanco, Hospital Gustavo Fricke, Viña del Mar; Alejandra Céspedes, Hospital San Juan de Dios, Santiago; Marta Werner, Hospital Guillermo Grant Benavente, Concepción; Tania Campos, Hospital Regional de Temuco; Camila Bolados, Hospital Regional de Puerto Montt; Miguel Angel Descalzo, WHO/PAHO consultant.

New Zealand: We thank Jacqui Ralston, Wendy Gunn and Jessica Danielecz at the Institute of Environmental Science and Research, Wellington. 
South Africa: We would like to acknowledge clinicians who participate in the Viral Watch influenza surveillance network and the Netcare Hospital Group for data on patient consultations.

\section{Conflict of interest}

CC received grant funding to the institute from Sanofi Pasteur, Programme for Applied Technologies in Health and United States Centers for Disease Control and Prevention, and travel funding from Parexel.

AvG has received research funding to the institute from Sanofi and Pfizer, and reimbursement of travel expenses from Sanofi and Pfizer.

\section{Authors' contributions}

All authors contributed text or data to the draft, interpreted results, and approved the final version of the manuscript. SGS coordinated the study, prepared the first draft and managed all revisions; KSC manages VicSPIN, MBMC manages ASPREN and both contributed data; SGS performed VE estimation for ILI surveillance; ACC conceived the study, contributed data, information and VE estimates for FluCAN, and contributed to development of the manuscript; SGS, VKYL, HP and YMD coordinated receipt of viruses for characterisation at the WHOCCRRI; YMD managed sequencing of viruses in Melbourne.

VS is coordinator for VE estimation in Chile and provided information about SARI surveillance and VE estimates; MFO manages SARI surveillance and with NV provided validated data from SARI surveillance; CG manages the national immunisation program and with PBur, provided information about vaccination; RAF and PBus managed virological surveillance activities; NEO and CSA provided support to the VE network in Chile and aided in drafting the manuscript.

QSH directs the National Influenza Centre in New Zealand, TW provided epidemiological data and VE estimates and both contributed to descriptions about influenza surveillance in New Zealand; AM, LL and TW managed surveillance data; JB and LJ were responsible for influenza testing and laboratory analyses of samples sent to ESR as part of the influenza surveillance program.

JMM, CC, OH, AvG and SW contributed surveillance data and VE estimates for South Africa, and provided relevant text and information during development of the draft. ST provided expert advice on surveillance VE estimation and contributed to developing the draft.

\section{References}

1. Paules $\mathrm{Cl}$, Sullivan SG, Subbarao K, Fauci AS. Chasing Seasonal Influenza - The Need for a Universal Influenza Vaccine. N Engl J Med. 2018;378(1):7-9. https://doi. org/10.1056/NEJMp1714916 PMID: 29185857

2. Sullivan SG, Chilver MB, Carville KS, Deng YM, Grant $\mathrm{KA}$, Higgins $\mathrm{G}$, et al. Low interim influenza vaccine effectiveness, Australia, 1 May to 24 September 2017. Euro Surveill. 2017;22(43). https://doi.org/10.2807/1560-7917. ES.2017.22.43.17-00707 PMID: 29090681

3. Cheng AC, Holmes M, Dwyer DE, Irving L, Korman T, Senenayake S, et al. Influenza epidemiology in patients admitted to sentinel Australian hospitals in 2016: the Influenza
Complications Alert Network (FluCAN). Commun Dis Intell Q Rep. 2017;41(4):E337-47. PMID: 29864387

4. Sotomayor V, Fasce RA, Vergara N, De la Fuente F, Loayza S, Palekar R. Estimating the burden of influenza-associated hospitalizations and deaths in Chile during 2012-2014. Influenza Other Respir Viruses. 2018;12(1):138-45. https://doi. org/10.1111/irv.12502 PMID: 29446231

5. Bissielo A, Pierse N, Huang QS, Thompson MG, Kelly H, Mishin VP, et al. Effectiveness of seasonal influenza vaccine in preventing influenza primary care visits and hospitalisation in Auckland, New Zealand in 2015: interim estimates. Euro Surveill. 2016;21(1):30101. https://doi.org/10.2807/1560-7917. ES.2016.21.1.30101 PMID: 26767540

6. Tempia S, Walaza S, Moyes J, Cohen AL, McMorrow ML, Treurnicht FK, et al. Quantifying How Different Clinical Presentations, Levels of Severity, and Healthcare Attendance Shape the Burden of Influenza-associated Illness: A Modeling Study From South Africa. Clin Infect Dis. 2019;69(6):1036-48. https://doi.org/10.1093/cid/ciy1017 PMID: 30508065

7. Kyeyagalire R, Tempia S, Cohen AL, Smith AD, McAnerney JM, Dermaux-Msimang V, et al. Hospitalizations associated with influenza and respiratory syncytial virus among patients attending a network of private hospitals in South Africa, 20072012. BMC Infect Dis. 2014;14(1):694. https://doi.org/10.1186/ S12879-014-0694-X PMID: 25510622

8. McAnerney JM, Walaza S, Tempia S, Blumberg L, Treurnicht FK, Madhi SA, et al. Estimating vaccine effectiveness in preventing laboratory-confirmed influenza in outpatient settings in South Africa, 2015. Influenza Other Respir Viruses. 2017;11(2):177-81. https://doi.org/10.1111/irv.12436 PMID: 27865064

9. Vega T, Lozano JE, Meerhoff T, Snacken R, Beauté J, Jorgensen $P$, et al. Influenza surveillance in Europe: comparing intensity levels calculated using the moving epidemic method. Influenza Other Respir Viruses. 2015;9(5):234-46. https://doi. org/10.1111/irv.12330 PMID: 26031655

10. Sullivan SG, Feng S, Cowling BJ. Potential of the test-negative design for measuring influenza vaccine effectiveness: a systematic review. Expert Rev Vaccines. 2014;13(12):157191. https://doi.org/10.1586/14760584.2014.966695 PMID: 25348015

11. Higgins JP, Thompson SG. Quantifying heterogeneity in a meta-analysis. Stat Med. 2002;21(11):1539-58. https://doi. org/10.1002/sim.1186 PMID: 12111919

12. Leung VK, Cowling BJ, Feng S, Sullivan SG. Concordance of interim and final estimates of influenza vaccine effectiveness: a systematic review. Euro Surveill. 2016;21(16):30202. https:// doi.org/10.2807/1560-7917.ES.2016.21.16.30202 PMID: 27124573

13. Krzywinski M, Altman N. Points of significance: Importance of being uncertain. Nat Methods. 2013;10(9):809-10. https://doi. org/10.1038/nmeth.2613 PMID: 24143821

14. Greenland S. Small-sample bias and corrections for conditional maximum-likelihood odds-ratio estimators. Biostatistics. 2000;1(1):113-22. https://doi.org/10.1093/biostatistics/1.1.113 PMID: 12933529

15. Mannino S, Villa M, Apolone G, Weiss NS, Groth N, Aquino I, et al. Effectiveness of adjuvanted influenza vaccination in elderly subjects in northern Italy. Am J Epidemiol. 2012;176(6):527-33. https://doi.org/10.1093/aje/kwS313 PMID: 22940713

16. Belongia EA, Skowronski DM, McLean HQ, Chambers C, Sundaram ME, De Serres G. Repeated annual influenza vaccination and vaccine effectiveness: review of evidence. Expert Rev Vaccines. 2017;16(7):723-26. https://doi.org/10.108 o/14760584.2017.1334554 PMID: 28562111

\section{License, supplementary material and copyright}

This is an open-access article distributed under the terms of the Creative Commons Attribution (CC BY 4.0) Licence. You may share and adapt the material, but must give appropriate credit to the source, provide a link to the licence and indicate if changes were made.

Any supplementary material referenced in the article can be found in the online version.

This article is copyright of the authors or their affiliated institutions, 2019. 